\title{
A NEW SPECIES OF ANDINIA SUBGEN. BRACHYCLADIUM (ORCHIDACEAE: PLEUROTHALLIDINAE) FROM COLOMBIA
}

\author{
Sebastián Vieira-Uribe ${ }^{1,2,5}$ \& Adam P. KarRemans ${ }^{3,4}$ \\ ${ }^{1}$ Sociedad Colombiana de Orquideología, Medellín, Colombia \\ ${ }^{2}$ Grupo de investigación en biodiversidad tropical - GIBIOT, Jardín Botánico de Medellín, Colombia \\ ${ }^{3}$ Lankester Botanical Garden, University of Costa Rica, P.O. Box 302-7050 Cartago, Costa Rica \\ ${ }^{4}$ Naturalis Biodiversity Center, Leiden, The Netherlands \\ ${ }^{5}$ Author for correspondence: utricseb@gmail.com
}

\begin{abstract}
Aвstract. A new species of Andinia belonging to A. subgenus Brachycladium from the eastern Andes of southern Colombia is described and illustrated. Andinia obesa is related to the A. nummularia species complex, characterized by the glabrous leaves, short inflorescences, an inconspicuous trilobed lip and a relatively large column. The new species can be distinguished by the unusually plump, orbicular, cucullate column with an incumbent anther.
\end{abstract}

Key words: Andinia, A. nummularia, A. obesa, Eastern Andes, Luer, new species

Introduction. Species of Andinia subgen. Brachycladium (Luer) Karremans \& S.Vieira-Uribe have been traditionally treated as members of genus Lepanthes Sw. (Luer 1994, Pridgeon 2005), mostly due to their Lepanthes-like flowers and what seem to be so-called "lepanthiform sheaths". However, the pendent plants, made up of long rhizomatous chains with multiple minute ramicauls, combined with the inflorescences shorter than the tiny, frequently pubescent leaves, make them unique within the subtribe. As a group they were recently given generic recognition under several different names as Brachycladium (Luer) Luer, Oreophilus W.E.Higgins \& Archila, Neooreophilus Archila, and Penducella Luer \& Thoerle. Nevertheless, a broad DNA-based phylogenetic analysis of this group of species placed them embedded within genus Andinia, a genus only distantly related to Lepanthes (Wilson et al. 2017).

The newly recircumscribed Andinia includes 72 species (Karremans 2016; Wilson et al. 2017), and $A$. subgen. Brachycladium is its largest subgenus with more than fifty species. Two sections have been recognized within the subgenus, A. sect. Brachycladae (Rchb.f.) Karremans \& S.Vieira-Uribe and $A$. sect. Amplectents (Luer) Karremans \& S.Vieira-Uribe. The first, to which the species described here belongs, is recognized by the glabrous leaves, with an entire margin, the flowers born on short pedicels, placed close to the leaf base, and especially the inconspicuous lip with the mid-lobe transformed into an appendix. Two species are currently accepted in Andinia sect. Brachycladae, Andinia nummularia (Rchb.f.) Karremans \& S.Vieira-Uribe and A. stalactites (Luer \& Hirtz) Karremans \& S.Vieira-Uribe; a third one is described here.

\section{TAXONOMIC TREATMENT}

Andinia obesa S.Vieira-Uribe \& Karremans, sp. nov.

TYPE: Colombia. Department of Putumayo: municipality of San Francisco, San José del Chunga, Yumartán Natural Reserve, 2500 m, Sept. 27, 2013, S. Vieira 0022 (holotype: JAUM!). Fig. 1.

DiAgnosis. Andinia obesa is characterized by the broad perianth parts, and especially the cucullate, orbicular, plump column with ventral anther. The new species is most similar to Andinia nummularia; however, it can be recognized by the overlapping, broadly-elliptic, up to $7.5 \mathrm{~mm}$ wide, leaves (vs. not overlapping, ovate, 5.0 $\mathrm{mm}$ wide), the broadly ovate and obtuse sepals (vs. oblong and acute), and the lateral lobes of the lip triangular with a linear-ligulate midlobe (vs. lateral lobes semilunate and midlobe triangular).

Plant epiphytic, repent and pendent, up to $20 \mathrm{~cm}$ long. Rhizome 4.5-5.0 $\mathrm{mm}$ long between ramicauls, 


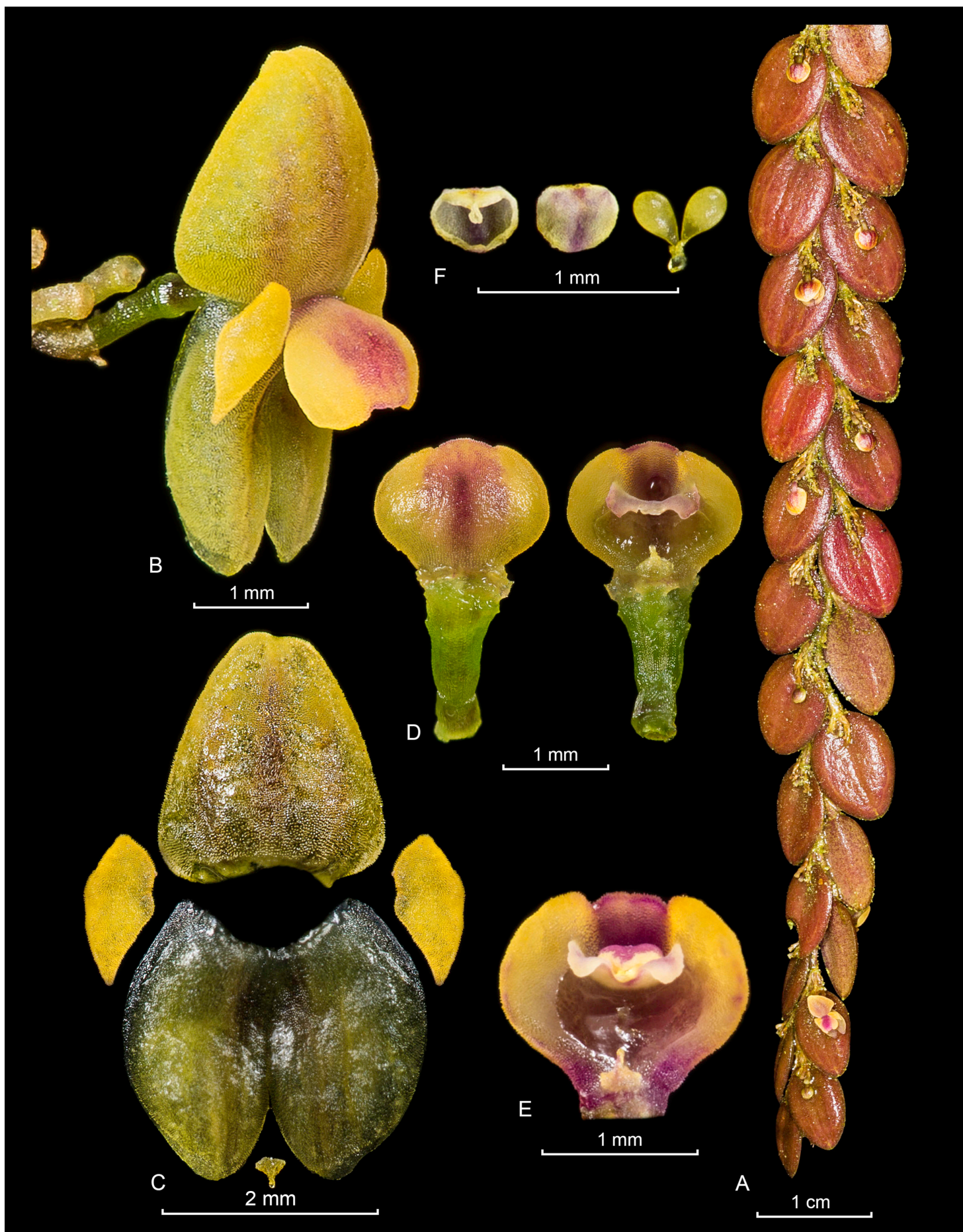

FIgure 1. Lankester Composite Dissection Plate (LCDP) of Andinia obesa S.Vieira-Uribe \& Karremans. A,habit. B, flower. C, dissected perianth. D, ovary with column and lip, dorsal and ventral view (pollinia and anther-cap absent). E, column, ventral view (pollinia and anther-cap present). F, anther cap and pollinia with drop-like viscidium. Photographs by S.Vieira-Uribe from the the plant that served as type. 


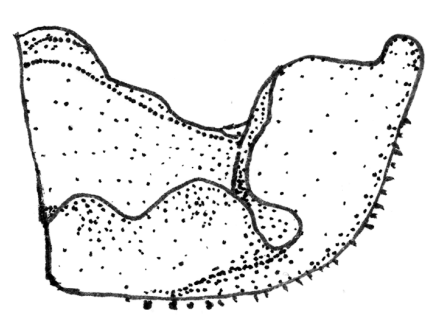

A
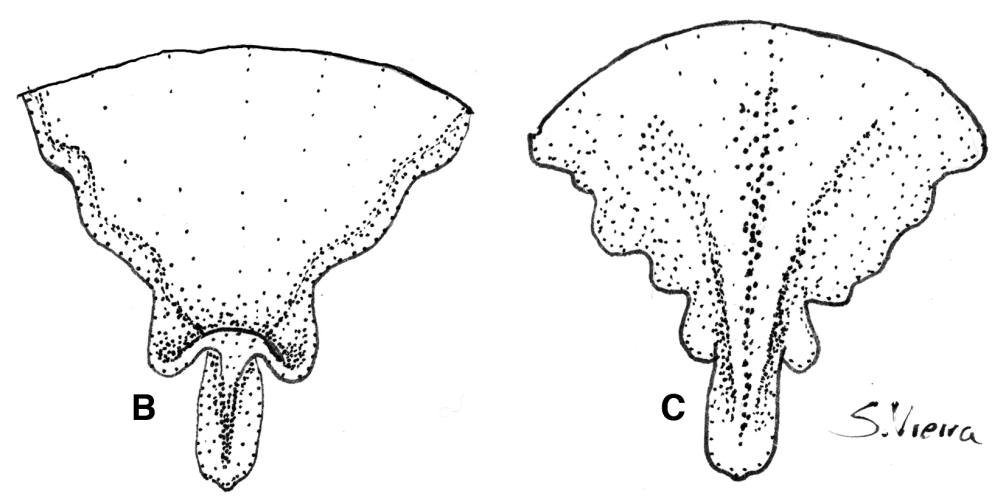

$0.5 \mathrm{~mm}$

Figure 2. Lip of Andinia obesa. A, side view. B, adaxial view. C, abaxial view. Drawing by S. Vieira-Uribe from the plant that served as type.

each segment enclosed by two imbricating, membranaceous, infundibular sheaths, glandular along the ribs, with dilated, glandular ostia. Roots slender, flexuous, ca. $0.4 \mathrm{~mm}$ in diameter. Ramicauls $1 \mathrm{~mm}$ long, distichous, enclosed by a single membranaceous, infundibular sheath glandular along the ribs, with dilated ostia 2.0-2.5 mm long. Leaves $10.0 \times 7.5 \mathrm{~mm}$, green to brownish red, thinly coriaceous, broadly-elliptic, obtuse, glabrous, slightly concave, margins revolute, retuse with a short abaxial apiculum at the sinus, the rounded base narrowing into a short petiole less than $0.2 \mathrm{~mm}$ long. Inflorescence a congested, successively flowered raceme placed on top of the leaf surface, producing up to five flowers; borne by a short slender peduncle ca. $0.7 \mathrm{~mm}$ long, enclosed by a glabrous infundibular sheath; up to five inflorescences are borne successively from near the base of each ramicaul; floral bracts tubular, oblique, acuminate, membranaceous, ca. $0.7 \mathrm{~mm}$ long; pedicels slender, persistent, $1.5 \mathrm{~mm}$ long; ovary green, glabrous, ca. $1.2 \mathrm{~mm}$ long. Flowers resting on top of the leaf, close to the middle. Dorsal sepal $2.1 \times 2.1 \mathrm{~mm}$, yellow, suffused with red along the veins, broadly ovate, obtuse, margins revolute, entire, minutely puberulous, 3 -veined, connate to the lateral sepals for about $0.3 \mathrm{~mm}$. Lateral sepals $2.4 \times 1.4 \mathrm{~mm}$, yellow, broadly ovate, obtuse, margins revolute, entire, minutely puberulous, 3 -veined, connate for about 1.3 $\mathrm{mm}$ into a synsepal. Petals $0.7 \times 1.4 \mathrm{~mm}$, yellow, transversally bilobed, minutely puberulous; the upper lobe broadly triangular, $0.5 \mathrm{~mm}$ long; the lower lobe obliquely triangular, $0.9 \mathrm{~mm}$ long. Lip $0.3 \times 0.3 \mathrm{~mm}$, yellow, minute, trilobulate, apiculate at the apex, entire, glabrous, abaxially puberulous along the middle vein, adnate to the base of the column, lateral lobes triangular, obtuse, midlobe linear-ligulate. Column $1.5 \times 1.6$ $\mathrm{mm}$ long, yellow, suffused with red along the middle, orbicular, cucullate, papillulose, the anther incumbent and stigma ventral; the rostellum white suffused with red. Pollinia two, yellow, ovoid, basally filiform, with a transparent drop-like viscidium. Anther cap creamyellow suffused with red, orbicular, cucullate.

Eтymology: From the Latin obesa (fat), in allusion to the plump appearance of the flower and its column.

Andinia obesa belongs to Andinia subgen. Brachycladium (Wilson et al. 2017), and among the species of that subgenus it can be recognized by the glabrous leaves, yellow flowers with broadly ovate sepals, the minute lip and especially the large, cucullate, orbicular, plump column with ventral anther. Within $A$. sect. Brachycladae, it is most closely related to $A$. nummularia, a species that has been considered morphologically variable (Luer 1994), and is likely to include several different species under its current circumscription (Wilson \& Jost 2009). Andinia obesa is quite unlike what was originally described by Reichenbach as Lepanthes nummularia based on the original protologue, type specimen, and accompanying illustration. The new species can be distinguished from the latter by the overlapping, broadly-elliptic, up to $7.5 \mathrm{~mm}$ wide, leaves (vs. not overlapping, ovate, $5.0 \mathrm{~mm}$ wide), the broadly ovate and obtuse sepals (vs. oblong and acute), and the lateral lobes of the lip triangular with a linear-ligulate midlobe (vs. lateral lobes semilunate and 
midlobe triangular)(Fig. 2). From Luer's very broad concept of A. nummularia (Luer 1994) the new species can be especially distinguished by the broad, orbicular, cucullate column with the incumbent anther (vs. clavate column, anther apical) and the linear-ligulate midlobe of the lip (vs. triangular).

Habitat and conservation status. Andinia obesa is frequent but very local at its only known locality. It is apparently restricted to elevations between 2300 and $2500 \mathrm{~m}$ in very wet, cloud forests, where it grows together with several other species of the same genus from $1 \mathrm{~m}$ upwards to the higher branches of the trees. The eastern Andes of southeast Colombia are quite unexplored, so the distribution of the species may also extend well north of the single known site (Sibundoy valley) and also possibly down to Ecuador. In light of the lack of exploration of suitable nearby habitat and the cryptic nature of the plants, we suggest classify- ing this species under the IUCN category "Data Deficient". The plants have been observed blooming in the months of September and December, and it is presumed that it can bloom during most of the year except during the driest part.

ACKNOWLEDGMENTS. This manuscript was prepared as part of a dedicatory issue commemorating the $95^{\text {th }}$ birthday of Carl Luer, who's extensive work on the Pleurothallidinae is the basis for most current studies in the subtribe, including the present. We want to thank Ramiro Medina from Sibundoy, the discoverer of this species, for providing its first photographs and information. Mario Camilo Barrera, from San Francisco, Putumayo, is thanked for guiding SVU while in Sibundoy Valley. Steve Beckendorf and Peter Tobias of the Orchid Conservation Alliance are thanked for the invitation to the first author to join a conservation trip to Sibundoy Valley. Mark Wilson and Lou Jost are especially thanked for their comments on the manuscript.

\section{LitERATURE CITED}

Karremans, A. P. (2016). Genera Pleurothallidinarum: an updated phylogenetic overview of Pleurothallidinae. Lankesteriana, 16(2), 219-241.

Luer, C. A. (1994). Icones Pleurothallidinarum XI: Systematics of Lepanthes subgenus Brachycladium and Pleurothallis subgenus Aenigma, subgenus Elongatia, Subgenus Kraenzlinella. Monographs in Systematic Botany from the Missouri Botanical Garden, 52, 28-31.

Pridgeon, A. M. (2005). Subtribe Pleurothallidinae. Pridgeon, A. M. Cribb, P. J. Chase, M. W. Rasmussen, F. N. (Eds.). Genera Orchidacearum. Vol. 4 Epidendroideae (Part One). Oxford: Oxford University Press (pp. 370--373).

Reichenbach, H. G. (1858). Xenia Orchidacea: Beiträge zur Kenntniss der Orchideen. F.A. Brockhaus, Leipzig, 346 pp.

Wilson, M. \& Jost, L. (2009). Evidence from DNA and sympatry resolves Brachycladium nummularius into at least five biological species. (Abstract of poster presented at 2nd Scientific Conference on Andean Orchids, Nov. 2007, Loja, Ecuador.) In: Pridgeon, A.M. \& Suárez, J.P. (Eds.) Proceedings of the Second Scientific Conference on Andean Orchids. Universidad Técnica Particular de Loja, Loja, Ecuador.

Wilson, M. \& Jost, L. (2011) Phylogenetic analysis of the Andean genus Brachycladium Luer (syn. Oreophilus Higgins \& Archila) and closely related genera based on nuclear ITS sequencing. (Abstract of poster presented at 3rd Scientific Conference on Andean Orchids, Feb. 2009, Quito, Ecuador.) Lankesteriana, 11, 370. doi: https://doi.org/10.15517/lank. v11i3.18305

Wilson, M., Frank, G. S., Jost, L., Pridgeon, A. M., Vieira-Uribe, S. \& Karremans A. P. (2017). Phylogenetic analysis of $A n-$ dinia (Pleurothallidinae: Orchidaceae) and a systematic re-circumscription of the genus. Phytotaxa, 295(2), 101-131. doi: https://doi.org/10.11646/phytotaxa.295.2.1 